TITLE:

\title{
Breaking through the Double Blockade: Inter-Atlantic Wartime Communications at Roche
}

AUTHOR(S):

Kurosawa, Takafumi

\section{CITATION:}

Kurosawa, Takafumi. Breaking through the Double Blockade: Inter-Atlantic Wartime Communications at Roche. Jahrbuch für Wirtschaftsgeschichte / Economic History Yearbook 2015, 56(1): 227-256

ISSUE DATE:

2015-01-01

URL:

http://hdl.handle.net/2433/203073

RIGHT:

The full-text file will be made open to the public on 1 May 2016 in accordance with publisher's 'Terms and Conditions for Self-Archiving'. 


\title{
Takafumi Kurosawa
}

\section{Breaking through the Double Blockade: Inter-Atlantic Wartime Communications at Roche}

\begin{abstract}
This paper examines the roles of information and knowledge sharing, and of communication in businesses during the interwar period and during World War II (WWII). It focuses on F. Hoffmann-La Roche Ltd. (Roche), a Swiss pharmaceutical company. During WWII, the Axis Powers and the Allies imposed a double blockade on Switzerland and Roche's market was divided between the two belligerent camps. Roche coped by mobilizing a unique twinstructure, a provision introduced during the interwar period, by transforming the ownership structure in terms of both ownership and control. While this strategy enabled its expansion in the U.S. market and safeguarded the group against various political risks, it also destabilized the group's unity. As intensive as it may have been, telecommunication across the Atlantic was not sufficient for sharing crucial knowledge and checking the U.S. subsidiary's thirst for independence. To control the situation, the financial director of Roche's Basel headquarters travelled to the United States, breaking the double blockade. Eventually, the on-site, face-to-face communication and a long-distance telephone call contributed to the survival of the company as a unified organization.
\end{abstract}

JEL-Codes: N 40, N 44, N 80, N 84

Keywords: information, knowledge, communication, multinational enterprise, holding company, business history, political risk, WWII, neutrality, Switzerland

\section{Introduction}

The multinational enterprise (MNE), one of the most important actors of globalization, originated before World War I (WWI) and developed in environments that had relatively few constraints imposed by sovereign states. The main ob-

Takafumi Kurosawa, Graduate School of Economics, Kyoto University, Sakyo-Ku, Yoshida Honcho, Kyoto City, 606-8501 Japan, E-mail: kurosawa.takafumi.6e@kyoto-u.ac.jp 
stacles to information exchange and communication were physical distance and technological conditions rather than political ones.

However, nationalism and the two world wars created new difficulties for multinational enterprises - communication in and out of these organizations was impaired by battlefronts and blockades. Furthermore, this new threat was closely linked to fatal risks for MNEs during the world wars, such as boycott, restraints on transactions involving foreign exchange, economic sanctions and blacklisting, asset freeze, loss of control over subsidiaries, and in some extreme cases, confiscation of subsidiaries and even of the parent company itself. Organizational capabilities to cope with these difficulties became decisive factors for the competitiveness and survival of MNEs. Some of the MNEs from Switzerland and other neutral countries enhanced their position in this process. ${ }^{1}$

In order to address these political risks, a sizable number of MNEs built up a complicated ownership and control structure for their businesses. ${ }^{2}$ However, it quite often involved the risk of weakening the grip on their subsidiaries and sometimes even led to the dismantlement of the whole group. The introduction of a complex company structure meant that the information and knowledge about the company became crucial and delicate elements for the survival of the company. Wartime communication among group companies was often affected by external, non-economic factors. This paper analyzes the challenges in information and knowledge transfer and communication in a multinational company which had to address political risks.

This paper focuses on the case of F. Hoffmann-La Roche \& Co. (since 1919, F. Hoffmann-La Roche \& Co. AG., hereinafter Roche), a pharmaceutical company

1 G. Jones/H.G. Schröter, The Rise of Multinationals in Continental Europe, Aldershot 1993; G. Jones, Multinationals and Global Capitalism from the Nineteenth to the Twenty-First Century, Oxford 2005, pp. 81-83, 243-244.

2 For a discussion of general political risk and its impacts on international businesses, see $H$. James/T. Jakob (Eds.), Enterprise in the Period of Fascism in Europe, Aldershot 2002; G. Jones, Control, Performance, and Knowledge Transfers in Large Multinationals. Unilever in the United States, 1945-1980, in: Business History Review 76/3, 2002, pp. 435-476; C. Kobrak/P. Hansen (Eds.), European Business, Dictatorship, and Political Risk, 1920-1945, New York 2004. For a discussion of the scheme of trust and holding structures, see $M$. Lüpold, Globalisierung als Krisenreaktionsstrategie. Dezentralisierung und Renationalisierung bei Nestlé 1920-1950, in: H.-J. Gilomen/M. Müller/B.Veyrassat (Eds.), Globalisierung-Chancen und Risiken. Die Schweiz in der Weltwirtschaft 18.-20. Jahrhundert/La globalisation-chances et risques. La Suisse dans l'economie mondiale 18e-20e siècles, Zurich 2003, pp. 211-234; B. Wubs, International Business and National War Interests. Unilever between Reich and Empire, 1939-1945, London 2008; G. Jones/C. Lubinski, Managing Political Risk in Global Business. Beiersdorf 1914-1990, in: Enterprise \& Society 13/1, 2012, pp. 85-119. 
based in Basel. Founded in 1896, Roche was an MNE since inception, with its headquarters in proximity to Alsace and its first main factory in Germany (Grenzach) across the national border. With subsidiaries and agencies in 35 countries, it had become Europe's second largest pharmaceutical enterprise by 1929, next only to IG Farben. ${ }^{3}$ Roche expanded its business outside Europe during the interwar period and during World War II (WWII), evolving from a European MNE to a truly global MNE. With the expanding U.S. market, the company faced a crisis caused by geopolitical distance, which threatened the unity of the group.

Several studies have examined the difficulties faced by Swiss multinationals located in the cross-border economic region during the two world wars and highlighted that these obstacles were overcome to a significant extent by geographical proximity. ${ }^{4}$ This paper focuses on the transfer of information and knowledge among the major actors in Roche, the constraints imposed by the double blockade, and the details of the communications between the two headquarters that were separated by the Atlantic. ${ }^{5}$

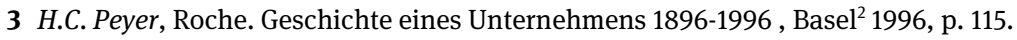

4 As regards WWI and the interwar period, Alexander L. Bieri, a curator at the Roche Historical Collection and Archive, has recently completed a study on the impact of WWI and nationalism on Roche, focusing on its ownership and control structure. A.L. Bieri, Roche im Ersten Weltkrieg. Die Genese einer globalen Unternehmensstruktur, in: Basler Zeitschrift für Geschichte und Altertumskunde, forthcoming. Dr. Bieri has kindly provided the author with the proof. As regards WWII, see, for instance, an intensive study on Georg Fischer A.G., a manufacturer of cast plumbing products and joints, that describes how and the extent to which communication across the Swiss-German border continued during WWII: H.U. Wipf, Georg Fischer A.G. 1930-1945: Ein Schweizer Industrieunternehmen im Spannungsfeld Europas, Zürich 2001. See also: L. Straumann/D. Wildmann, Schweizer Chemieunternehmen im "Dritten Reich", Zurich 2001; C. Ruch/M. Rais-Liechti/R. Peter, Geschäfte und Zwangsarbeit. Schweizer Industrieunternehmen im "Dritten Reich", Zurich 2001. For discussion related to Switzerland and the issue of knowledge during WWII, see: Independent Commission of Experts Switzerland - Second World War, Switzerland, National Socialism and the Second World War: Final Report, Zürich 2002 (hereinafter ICE, Final Report).

5 Roche's twin structure is not discussed in detail in this paper; preliminary research results on this subject were presented in T. Kurosawa/B. Wubs, Comparing Organizational Change of Swiss and (Anglo)-Dutch Multinationals as a Result of the Two World Wars (EBHA-EBSJ Paris 2012 Conference Paper), Paris 2012. Related publications (in Japanese) include the following: $T$. Kurosawa, Churitsukoku Suisu to Nachizumu. Dainiji Sekaitaisen to Rekishi Ninshiki [Neutral Switzerland and National Socialism: The Second World War and Perception of History], Kyoto 2010; Idem, Dainiji-Taisen Nijyu-no Fusa to Churitsukoku Suisu no Takokuseki Kigyo [The World War, Nationalism and Organizational Structure of European Multinational Enterprises: The Twin Structure of Nestle, Roche and Unilever] in: The Kokumin-Keizai Zasshi [Journal of Economics \& Business Administration] 202/5, 2010, pp. 1-21. 
The second section of this paper presents the backdrop to the story: the impact of and the lessons learned from WWI from the company's perspective and the provisions made by the company to address political risks during the interwar period (2.1); the features of the double blockade imposed by the Allies and the Axis Powers on Switzerland and the motivations for this blockade (2.2); and the asymmetries between the Allies and the Axis Powers, and the background to the perceptions and actions of the various actors (2.3).

The third section forms the core of this paper. We trace relevant historical events focusing on communication involving three main figures - Emil Barell, President of the Roche group, Alfred Fuchs, Financial Director of Roche's headquarters in Basel, and Elmer H. Bobst, the General Director (later President) of Roche's American subsidiary (Roche US) in Nutley. As financial director, Fuchs was the key person responsible for Roche's group structure (i.e. ownership and control). He travelled to the United States twice, crossing the Atlantic during wartime and breaking the double blockade, to deal with the risk of the group's dismantlement.

Most of Fuchs's perceptions and behaviours discussed in this study were reconstructed from his unpublished autobiography, ${ }^{6}$ which by nature is subjective. However, the author verified most of his footprints, arguments, actions, and the logic behind them using other first-hand material preserved at the Roche Historical Archive.

This paper aspires to answer the following questions: What kind of communication was maintained among the key actors during WWII? To what extent could they exchange their information and knowledge, and by what means and through which paths did they do so? What was the impact of the political uncertainty and scarcity of information on their communication and behaviour? Why and when did they venture into direct, face-to-face communication by making risky trips across the Atlantic Ocean? To what extent were the political risks different from the non-political, economic ones? What kind of information asymmetry and knowledge asymmetry existed, and how were they rooted in the asymmetry of experience and expectation for the (desirable and undesirable) future? What was the role of trust among the major actors?

6 Roche Historical Archive, Document Nr.PE.2. FUA 101483. Alfred J. Fuchs (1884-1968), Aus meinem Berufsleben. Vol. I and Vol. II, n.d. About this typewritten autobiography, Fuchs stated, "I started to write in 1953" (Vol. I, page 405); however, it is not known when and how the completed work was disclosed to others. Roche Historical Collections and Archive compiled a limited edition (printed and PDF versions) from the typewritten copy solely for in-house distribution, but the new version does not indicate page numbers. Consequently, I cite the typewritten version of the copy as “A. Fuchs, Aus meinem Berufsleben” hereinafter. 


\section{The Double Blockade: Swiss neutrality and challenges for Swiss MNEs}

\subsection{Lessons learned from WWI and provisions during the interwar period}

In this section, we focus on individuals' perceptions during the interwar period and WWII. Some of the perceptions and behaviour of individuals and organizations during WWII appear to be irrational when analysed today. A common explanation is that these people made their judgments based on their memories and experiences of WWI. This could also explain why some actors trusted or mistrusted others. Most of the key persons who made strategic decisions during WWII had experienced WWI at a young age; they went on to become leaders of the next generation.

A brief description of the experiences of Roche during WWI and the provisions it made after the end of the war help set the background for the discussion in this paper. ${ }^{7}$ Before the outbreak of WWI, Roche had established its biggest factory in Grenzach in German territory; this factory supplied materials and semi-finished products to Roche's other factories. Both the Allies as well as the Central Powers were its main markets. Once the war broke out, the company suffered from a disruption of its supply chain and the communication between headquarters and subsidiaries. Moreover, Roche had to face a boycott campaign by local competitors in both camps; another setback was the arrest of Emil Barell (1874-1953), the director of its main factory in the German territory close to Basel, and his subsequent house arrest in Berlin. The company overcame these setbacks by making the headquarters in Basel neutral (i.e. any member of the management who was a national of any belligerent country was replaced by a Swiss national), expanding its production facilities in Basel, and legally localizing its foreign assets.

The company faced the impending risk of bankruptcy in 1918/19 owing to difficulties during WWI and a sharp drop in its foreign currency asset value. In the midst of a serious liquidity crisis, Roche's founder-owner, Fritz Hoffmann, (1868-1920) was forced by his brother-in-law and president of Basler Handelsbank, Rudolf Albert Koechlin-Hoffmann, to reorganize the company as a joint

7 Roche was established as a pharmaceutical manufacturer, not as a general chemical producer, during the late $19^{\text {th }}$ century; see Peyer, Roche, p. 35. 
stock company, F. Hoffmann-La Roche \& Co., A.G. ${ }^{8}$ The following year, after the demise of Fritz Hoffmann, Barell assumed the role of Managing Director ${ }^{9}$. After the founder's demise, and particularly after one of the founder's sons sold his share to Barell in 1924, Barell became a power to contend with at Roche, as its Managing Director and a large shareholder. ${ }^{10}$ Although the ownership structure underwent slight modifications, throughout the interwar period and WWII, Roche's shares were not listed on any stock exchange and were held by a limited number of shareholder groups. ${ }^{11}$

During the 1920s, the company began to re-centralize gradually. However, the reconstruction of a stable world economic order failed. To cope with the collapse of the Doppel Reich, the segmentation of its market into the patchwork of territories of the newly-born nation states, and the double taxation on the parent company as well as its local subsidiaries, Roche introduced a special twin structure comprising of two holding companies - Roche and Sapac (described in Section 2.1).

Until recently, World War I had long remained a "forgotten economic war". ${ }^{12}$ While it was a precursor to WWII in many ways, the experience of WWI differed significantly in each country. ${ }^{13}$ More to the point, WWII was not a repe-

8 Before this reorganization, Roche was a partnership company owned by members with unlimited liability and one with limited liability. Basler Handelsbank was Roche's Hausbank or primary banker and Fritz Hoffmann's major creditor; see Ibid, p. 74, pp. 77-81; A.L. Bieri, Roche im Ersten Weltkrieg.

9 Emil Barell returned from Berlin to Basel after the WWI. He was an authoritarian leader of the company, who retained his position until right before his death; see Straumann/Wildmann, Schweizer Chemieunternehmen, p. 186.

10 Peyer, Roche, pp. 77-80.

11 The company has always been regarded as a family-owned business by the Swiss public. Because all Roche shares were bearer shares at that time, it is not easy to get a reliable record of its ownership. However, A.L. Bieri elucidated that the ownership and the importance of the founder family can be categorized into several phases. Between the mid-1920s and mid-1930s, the proportion of shares held by the narrowly defined founder family was smaller than other period. At that time, Basler Handelsbank and a group of shareholders under Barell's control had significant importance; see Beiri, Roche im Ersten Weltkrieg.

12 R. Rossfeld/T. Straumann (Eds.), Der Vergessene Wirtschaftskrieg. Schweizer Unternehmen im Ersten Weltkrieg, Zürich 2008.

13 The contrast between Belgium (which was occupied twice) and the Netherlands (which maintained neutrality during WWI) is an outstanding example. See: H. Klemann, Occupation and Industry. The Industrial Development in the Netherlands, 1940-1945, in: J. Lund (Ed.), Working for the New Order. European Business under German Domination, 1939-1945, Odense 2006, pp. 45-74; D. Luyten, The Belgian Economic Elite between Economy and Politics, in: Lund, Working for the New Order, pp. 75-92. 
tition of WWI. Unlike the previous world war, WWII was very much expected, making it significantly different from WWI. The effects of this expectation and the preparation for the war were two-fold. For some actors, being prepared helped them to survive, but for others, it served as a lethal pitfall.

\subsection{New experience of WWII: Double blockade imposed on neutral Switzerland}

For Switzerland, a land-locked country in the heart of Europe, the situation after May 1940 was completely new and different from what it had experienced during WWI, because the country was surrounded by one of the belligerent camps (the Axis Powers). This was a situation unprecedented since the end of the Napoleonic War. After the occupation of other small neutral states, Switzerland found itself in a unique position. Only Sweden had some similarities to Switzerland in this respect. ${ }^{14}$

Inner Blockade: This encirclement of Switzerland by the Axis Powers can be regarded as an inner blockade when compared to the outer blockade imposed by the Allies (discussed later). It had two aspects. On the one hand, it was a selfblockade of sorts by Switzerland for the purpose of defence. On the other hand, it was a forced blockade from outside based on the Axis Powers' strategy.

Switzerland had many reasons to consider a self-blockade. The country was geared up for a possible German invasion and the influx of refugees. Its official plan of action in the event of German invasion was to abandon its major cities and retreat into a fortress in the heart of the Alps. After the surprisingly quick defeat of France, it became obvious that this kind of military resistance would be ineffective, though this widely shared perception was forgotten after the war. Nonetheless, armed neutrality and resistance against invasion were at the very core of Swiss neutrality; thus, self-blockade and border patrol were the logical consequences.

The Axis Powers had their reasons to impose an external forced blockade on Switzerland. For Nazi Germany, mobilizing material resources in Switzerland was of little significance. Instead, utilizing neutral Switzerland as a gateway to the outside world, especially to maintain and expand relations with other neutral countries (including those outside Europe), was of primary interest. ${ }^{15}$ Securing

14 M. Fritz, Swedish Adaptation to German Domination in the Second World War, in: Lund, Working for the New Order, pp. 129-140.

15 ICE, Final Report. 
trans-Alps transit was also important. For these purposes, the Axis Powers took control over the export of coal to Switzerland; they also took control over the border. Control over confidentiality was another reason driving the Axis.

However, these voluntary and forced blockades did not mean that Switzerland was completely cut off from the outside world. Studies since the late 1990s showed that Switzerland communicated extensively with its neighbours during the war. ${ }^{16}$ This is not surprising given that the major economic centres of Switzerland always had their economic hinterland beyond the border. ${ }^{17}$ During WWII, even when the border was closed occasionally, some of Swiss managers and engineers from the home factory in Switzerland were issued a Grenzkarte to visit the subsidiary factories in Germany. ${ }^{18}$ Though German control on crossborder communications grossly intensified, geographical and personal proximity compensated for this to a certain extent.

Some Swiss MNEs almost lost control over their German subsidiaries, especially where the German market had a large sales share in the whole group and in the case of armament-related industries as well. However, geographical proximity remained decisive. Roche's subsidiary in Berlin enjoyed an increase in sales thanks to exports to the German-dominant areas and due to military demand. In 1941, two German executive officers of Roche Berlin started to act arbitrarily and attempted to take control of the subsidiaries in German-occupied areas. However, the general manager of the Grenzach plant stood up for the Swiss headquarters; Roche overcame this crisis by removing the two German directors. ${ }^{19}$

Outer Blockade: The blockade on the Swiss border was not the only one for Switzerland. After the United Kingdom successfully retained air supremacy in the Battle of Britain and Germany abandoned its attempts at amphibious landing in that country, continental Europe - which was under the hegemony of Nazi Germany - was externally blockaded by the Allies. The Axis fortified the shores against the Allies' counterblow. In this way, the second blockade - the outer blockade -- was formed. Thus, neutral Switzerland was besieged by a double blockade.

16 Wipf, Georg Fischer; Straumann/Wildmann, Schweizer Chemieunternehmen; Ruch/RaisLiechti/Peter, Geschäfte und Zwangsarbeit; ICE, Final Report; Kurosawa, Churitsukoku Suisu to Nachisumu.

17 T. Kurosawa, Kindai Suisu Keizai no Keisei. Chiiki-Shyuken to Kou-Rain Chiiki no Sangyo Kakumei [The Formation of the Modern Swiss Economy: Regionalism and the Industrial Revolution in the Hoch-Rhein Region], Kyoto 2002.

18 Wipf, Georg Fischer, pp. 204-205.

19 Peyer, Roche, p. 163. 
The closure imposed by the outer blockade was also incomplete for several reasons. For Switzerland and Swiss MNEs, Nazi Germany's counter-blockade had a relatively low impact because of the differences in attitude toward blockades or embargos, which reflected the asymmetric positions of the actors.

With regard to Nazi Germany's attitude toward this outer blockade, it is noteworthy that Swiss trade with the Allies was permitted to a certain extent. Germany issued the Geleitschein (a free navigation certificate) and allowed the Swiss fleet through the blockade barrier, ${ }^{20}$ though the path tended to be narrower in the later phase of the war. Watch movement manufacturers in Switzerland exported large quantities of mechanical time fuses to the United States, which were destined for military use. ${ }^{21}$ Nazi Germany used this generous policy for diplomatic clout over Switzerland, similar to its permission for the Gothenburg traffic that it used against Sweden. ${ }^{22}$

The Allies' equivalent of the Geleitschein was the allocation of trade quotas for raw materials, energy, and food for domestic consumption in Switzerland. The Allies viewed any supply of such materials to areas under German control with scepticism, as this could undermine their economic warfare. The Allies attempted to control all the inflow and outflow of materials and information across its blockade barrier. Switzerland and Swiss companies were the primary targets of their suspicion because of their historically strong ties with Germany.

Finally, the communication costs associated with the trans-Atlantic sharing of knowledge were far higher than the costs for cross-border communication between Germany and Switzerland. The differences in cost stemmed not from the brutal characteristics of the dominant regime but from difficulties due to sheer geographical distance.

However, the existence of other neutral countries (especially Spain and Portugal) made the blockade incomplete. ${ }^{23}$ This loophole afforded by Portugal's neutral status was exploited by Roche for communicating with the Western hemisphere.

20 Ruch/Rais-Liechti/Peter, Geschäfte und Zwangsarbeit, p. 158.

21 ICE, Final Report, pp. 200-201.

22 Fritz, Swedish Adaptation, pp. 133-134.

23 The Allies launched the Safehaven operation to prevent the flight of Nazis and their assets outside the blockade; see L.-M. Martin, Safehaven. The Allied Pursuit of Nazi Assets Abroad, New York 2007. 


\subsection{Asymmetric resources and strategy: Risks for MNEs in occupied and neutral countries}

The double blockade was an outcome of military necessity and the economic warfare tactics of the two belligerent camps. However, the resources that needed to be mobilized and the geopolitical position in the world revealed a distinct asymmetry between the two camps. This was one of the reasons for the asymmetric attitude toward MNEs. Although Nazi Germany dominated the European continent, from a global perspective, the area under Nazi-German control was surrounded by the Allies' domain. With their abundant resources, depriving the enemy of supplies was a far bigger priority for the Allies than increasing their own resources.

In this context, the Trading with the Enemy Act (of 1939 for the United Kingdom and of 1917 for the United States) became the Allies' most important strategic measure. During WWII, The Trading with the Enemy Act was applied not only to individuals and to companies that belonged to enemy nations, but also to those under the influence of the enemy. ${ }^{24}$ That is, all assets and economic activities in the Axis-occupied territories were classified as belonging to the enemy. This posed a serious problem to the globalized Swiss (and other European) MNEs. Even when the overseas assets of such MNEs were safeguarded from German invasion because of the spatial distance from Europe, if the parent company fell under German occupation, their overseas assets were deemed transferable to the Allies' custody. ${ }^{25}$

In the event of an invasion of Switzerland, there was almost no way the Swiss MNEs could safeguard their European businesses. The loss of control and ownership in the sphere of Nazi dominion and the introduction of a German custodian (Verwalter) for management were likely to happen, even if an immediate surrender were to lessen material and human damages. ${ }^{26}$ Moreover, the

24 Wubs, International Business, p. 80.

25 To what extent the principle of the Trading with the Enemy Act was rational from the perspective of the Allies' economic warfare is an open-ended question. However, the plans for postwar occupation and the policies for war reparations/compensation were still under discussion at that time. In addition, the policy of capturing as much as possible was part of the Allies' basic plan of containing the Axis Powers in the continent and depriving them of their power as soon as possible.

26 Wubs, International Business, pp. 77-79, 84-87, 107-109. For an extreme case of immediate surrender and successful adjustment, see: J. Lund, Business Elite Networks in Denmark. Adjusting to German Domination, in: Lund, Working for the New Order, pp. 115-128. 
transfer of dividends and license fees to Europe from outside would be completely blocked.

Therefore, for Swiss MNEs with large overseas shares in sales and assets, the handling of their overseas assets and communicating with the Allies through the outer blockade became the most crucial determinants of their survival for which they could be prepared. To avoid losing company property and human resources both in Europe as well as overseas, they needed to separate their assets in the two belligerent camps while maintaining de facto control over their overseas concerns. This was quite a challenge because they had to conceal their ownership and management structure from the Allies as well as the Axis Powers. It was not certain whether the Allies would in fact implement the Trading with the Enemy Act or transfer the overseas assets of Swiss MNEs if Switzerland were to fall under Axis occupation.

Historians now know that Unilever, an Anglo-Dutch MNE, encountered similar problems because one of their headquarters was situated in the Netherlands; they received mild treatment at the hands of the Allies. However, even in the case of this half-British MNE, the eventual development was highly uncertain and they introduced extremely complicated provisions for ownership transfer by using layers of dummy companies and a trust scheme. ${ }^{27}$

For Swiss MNEs, rather than the knowledge of their products, technologies and markets, the knowledge of their own organization became the most crucial factor for their survival in such a situation.

\section{Roche and WWII: \\ Twin structure and trans-Atlantic communication}

\subsection{Twin structure (Roche-Sapac), relocation to Panama, and emergence in the U.S. market}

In Roche's case, its central provision for addressing the political risk was a special holding and corporate structure with twin holding companies - Roche and Sapac. These companies were often called parallel companies (Parallelgesellschaften) and were initially formed between 1926 and 1927.

Originally, this unique structure was introduced to cope with the increasing double taxation on the parent company and its subsidiaries as well as the seg-

27 Wubs, International Business, pp. 80-84. 
mentation of the markets after the disintegration of the Habsburg Empire. The introduction of a new tax system and a flexible company law in Liechtenstein provided the conditions required for this organizational innovation..$^{28}$ Later, this scheme started to serve the more important aims of addressing the increasing nationalism and avoiding the ultimate risk of confiscation by the belligerent authorities. ${ }^{29}$

After the reorganization, the two holding companies, Roche and Sapac, formed the two cores of the ownership structure of the group. To start with, the Roche headquarters in Basel had directly owned the shares of its foreign subsidiaries; after 1927, the shares were gradually transferred to Sapac, which was established in Liechtenstein.

The Sapac share was deemed identical to the Roche share, and Roche shareholders were assigned a Sapac share for every Roche share they owned. The shares of the two companies were deemed inseparable. Roche shareholders received dividend from both companies; however, the Sapac shares were set aside for management by trust businesses, thereby precluding the possibility of direct disposal of shares by Roche shareholders..$^{30}$

The Roche group of businesses was now reorganized as unique identical twins, each independent from the other with no capital ties, but sharing the same shareholder composition by virtue of their articles of incorporation.

In March 1938, just after Nazi Germany's annexation of Austria, Roche relocated Sapac from Liechtenstein (which came to share borders with the Third Reich) to Panama on the other side of the Atlantic. At the end of the same year, Roche's president, Barell, came back from his business trip to the United States and asserted that their business focus should be on the West (by which he meant the United Kingdom, Anglo-America, and Latin America). Thus, the board decided to scale down the expansion plans for the research institute in Basel and assign these resources to the United Kingdom and the United States. ${ }^{31}$

28 C.M. Merki, Wirtschaftswunder Liechtenstein. Die rasche Modernisierung einer kleinen Volkswirtschaft im 20. Jahrhundert, Zurich 2007, pp. 136-150.

29 For a discussion on the issue of corporate governance during the interwar period in Switzerland, see: M. Lüpold, Der Ausbau der „Festung Schweiz“: Aktienrecht und Corporate Governance in der Schweiz, 1881-1961, (Diss. Zurich) 2008. (Available online: http://www.ub.unibas.ch/digi/a125/sachdok/2011/BAU_1_5587831.pdf, 07-09-2014).

30 Roche Historical Archive, Documents Nr. Fa. 8.2 102300b, 14.01.1966: Nr. FR. 03-106047, Dr. A. von Sprecher, "Notiz zur Entwicklung der Roche-Statuten und des Verhaeltnisse Roche/ Sapac, 17.04.1963.

31 Peyer, Roche, pp. 152, 177-178. 
Roche's financial director Fuchs talked about foreseeable risks as the reason for relocating Sapac from Liechtenstein to Panama. ${ }^{32}$ If the company had not relocated and Germany had annexed Liechtenstein, all of Sapac's income would have been transferred to Germany. The payment of Sapac's dividend to its shareholders would be blocked. Moreover, there was the risk that German authorities might uncover their carefully guarded secret: that all the shares of Roche Germany were indirectly owned by Roche shareholders.

However, after Roche's relocation to Panama, the most serious managerial difficulty during the war was not control over the twin holding company, Sapac; rather, it was control over the U.S. subsidiary in Nutley. In the following section, we discuss the challenges posed by the desire for independence expressed by Elmer H. Bobst, the head of Roche's U.S. subsidiary.

\subsection{Conflicts within the group: Challenges posed by American subsidiary and Bobst}

Roche's U.S. business was almost half a century old when aspirations for making it independent were first expressed. Its penetration into the U.S. market had begun in 1895 with the establishment of a sales agency and moved into high gear with the founding of a subsidiary in $1905 .{ }^{33}$ In 1921, the U.S. subsidiary experienced some financial difficulties, but Barell managed to steer out of it by drastically reducing headcount, consolidating his authority by dispelling veteran and family board members, and establishing governance by professional management. After these measures were initiated, the U.S. subsidiary made a Vshaped recovery in revenue under the leadership of General Director Elmer $\mathrm{H}$. Bobst, an American national. In fact, its revenue went on to surpass that of the German subsidiary in 1926 and eventually that of the Basel headquarters in 1929. In 1921, it kicked off full-fledged local production and relocated its production base from New York to Nutley, New Jersey in 1929.

Roche's U.S. subsidiary began to aspire for independence; this became known at the culmination of the unprecedented boom in the American economy and share prices. In July 1929, Bobst (the General Director of Roche US) visited Roche's headquarters in Basel along with investment bankers from New York; their agenda was to propose shocking acquisition deals. One was for the acqui-

32 A. Fuchs, Aus meinem Berufsleben, Vol. II, pp. 140-141.

33 Roche's FDI in the United States was analyzed in M. Wilkins, The History of Foreign Investment in the United States 1914-1945, Cambridge 2004. 
sition of the entire Roche group for USD 25 million; the other was for the acquisition of Roche's U.S. subsidiary for USD five million. The board of directors (Verwaltungsrat) in Basel immediately rejected these abrupt and presumptuous proposals from its U.S. subsidiary. Four months later, on October $24^{\text {th }} 1929$, stock prices at the New York Stock Exchange (NYSE) plunged, leading to the collapse of the world economy. In the middle of the Great Depression, the acquisition proposals were forgotten. However, this did not discourage Bobst from pursuing his ambition of securing independence from the parent company in Switzerland. ${ }^{34}$ He remained tenacious and bided his time. After the rapid expansion of their U.S. business, when the sales in the United States surpassed those of the Basel headquarters in 1936, he proposed the listing of the U.S. subsidiary on the NYSE.

Bobst argued that this move was necessary to raise USD three million; this capital was required to finance the rapidly expanding U.S. business. He pressed that it was necessary to introduce American capital to Roche's U.S. subsidiary, in which Roche (or more precisely, Roche's shareholders) had 100 percent stake at that time (via Sapac in Panama), emphasizing the significance of becoming more localized amid the growing economic nationalism in the United States. ${ }^{35}$ This knowledge about the market and the U.S. political environment was the very information that could not be verified without being on site.

It was in this context that Roche's president Barell decided to send Alfred J. Fuchs (1884-1958), the financial director of Roche, to the United States. Fuchs was Barell's right-hand man. ${ }^{36} \mathrm{He}$ had worked in Wall Street before joining Roche in 1926. He was in charge of the quinine business, which remained the most important segment for the company until the late 1920s. This business had a dominant international cartel of which Roche was a member. Fuchs always accompanied the president without any other companions to international meetings of the quinine cartel, which were convened every year at different locations. This experience forged a deep bond of trust between them.

Fuchs travelled from Bremen by boat and arrived in New York in the early spring of 1936. Bobst tried to win him over with lavish entertainment. The American also took Fuchs to Hornblower \& Weeks, an investment bank in Wall Street that was arranging the issuance of new shares as a candidate underwriter. Bobst argued that minority interest was not sufficient to achieve their goal. Fuchs's

34 Peyer, Roche, pp. 62, 73, 109, 115, 151.

35 For a description of Fuchs' experience in the United States in 1936, see: Fuchs, Aus meinem Berufsleben.

36 Fuchs, Aus meinem Berufsleben, Vol. II, pp. 121-127. 
counterproposal was the issuance of preferred shares with a reacquisition clause in lieu of the general stock (Stammaktien) with voting right; however, the local manager opposed this proposal. Upon his return to Basel, Fuchs reported directly to Barell. The information he brought was not limited to practical issues. He also reported that Bobst had a personal ambition - to gain a large number of the newly issued shares. He expressed deep concern and alarm that this financial deal might endanger the unity of the group because it could split the interests of the Basel headquarters and its U.S. subsidiary. ${ }^{37}$

Fuchs's report was considered reliable because it was based on the handson information that he had gathered through conversations and observations on site. It was also supported by his deep and systematic knowledge of the U.S. financial market and the company's own organization, especially its financial structure. Based on Fuchs's report, Bobst's proposal was rejected once again. ${ }^{38}$

\subsection{Outbreak of WWII: Evacuation and legal arrangements (September 1939- April 1940)}

On September $15^{\text {th }} 1939$, a fortnight after the outbreak of the world war, ${ }^{39}$ the Roche board approved a resolution sanctioning the relocation of its headquarters in case of an emergency (without specifying any date); this was meant as a security measure in the event of a German invasion of Switzerland. ${ }^{40}$ Simultaneously, letters of resignation from all the board members were entrusted with the company's attorney, and a document to invalidate the board members' signatures was prepared, as security against possible aggression by the occupying force(s).

Barell insisted on relocating the headquarters to the United States, but the other board members objected to his proposal. It was decided to relocate the headquarters to Lausanne instead..$^{41}$ On November $3^{\text {rd }} 1939$, the board passed a

37 Ibid., p. 127.

38 Ibid., pp. 130-131.

39 A few years before the German attack on Poland (around 1936-1938), a top executive at Roche had predicted that Germany would wage another war, based on information obtained through its international cartel network regarding Germany's excessive stockpiling of quinine; Fuchs, Aus meinem Berufsleben, Vol. II, p. 133.

40 See: Ibid., pp. 159-160. An automatic change in the place of registration to the location of the government in exile was made possible by an amendment made the next month: see Wipf, Georg Fischer, p. 144.

41 Straumann/Wildmann, Schweizer Chemieunternehmen, pp. 179-180. 
resolution to relocate the company's registered address from Basel to Lausanne, with the possibility of moving it further to Paris, London, or even New York in the event of a more imminent threat. At that stage, the memory of WWI and especially the experience of trench warfare, was still dominant. Therefore, a nominal relocation to Lausanne was considered meaningful, rational, and sufficient. After the division of Poland during the course of the peculiar war, the plan to evacuate to Lausanne was suspended and the business continued to operate out of Basel. ${ }^{42}$ During this period (before Operation Weserübung was launched on April $9^{\text {th }} 1940$ in the North), Barell and Fuchs travelled to Amsterdam and Brussels for the annual meeting of the quinine cartel.

During this period of anxiety and temporary relief, Roche pressed ahead with additional preparations for a war. The ownership of Roche UK was transferred from the Basel headquarters to Sapac, which was now located in Panama City. In October 1940, Fuchs visited London for the legal transfer of ownership. ${ }^{43}$ The U.K. visa application process was tedious; finally, the British Consulate issued Fuchs a visa with a fixed departure date. Fuchs travelled to Boulogne via Paris and took a boat across the English Channel. In the United Kingdom, Swiss Bank Corporation and Nadir Corporation in Panama City handled the formalities. ${ }^{44}$

\subsection{Second phase of WWII: Besieged Switzerland and flight of Barell to the United States (April/May 1940)}

Six months after the outbreak of WWII, the situation changed dramatically and abruptly. On April $9^{\text {th }} 1940$, Operation Weserübung opened up a new front in the North. In a month, the German invasion of the Netherlands, Belgium, and Luxemburg as well as the Battle of France (May 10 ${ }^{\text {th }} 1940$ ) changed the entire geopolitical landscape of Europe. Following Italy's declaration of war (June $10^{\text {th }}$ 1940) against the Allies and the surrender of France (June $22^{\text {nd }} 1940$ ), Switzerland was besieged by the Axis Powers.

This prompted the evacuation of citizens from the northern border area toward the south of the country. As early as May, Barell declared that the time had

42 Ibid., pp. 179-180.

43 Fuchs, Aus meinem Berufsleben, Vol. II, pp. 161-163.

44 The Nadir Corporation in Panama was founded by Roche, and its capital was owned by Sapac. This dummy company was also used for gold transactions in London, which were arranged to address the worsening foreign exchange situation; see Ibid., pp. 97-106. 
come to evacuate from Basel, although his fellow directors (members of Direktionsausschuss, the executive officers) did not welcome this decision. Roche eventually arranged an office at the Savoy Hotel in Lausanne, stockpiled a certain amount of material in a warehouse in Lausanne, and reserved a factory. ${ }^{45}$

However, this limited evacuation plan was far from satisfying for Barell who had a Jewish wife and had lived under house arrest in Berlin during WWI. He had frequent telephone calls with Bobst regarding this issue, which convinced him to immigrate to the United States. On May $21^{\text {st }} 1940$, Barell nominated new executive officers; this decision was approved by the board of directors (Verwaltungsrat) that afternoon. Fuchs retained his position as executive officer. Barell left for Genoa immediately and travelled further to New York, accompanied by his family. ${ }^{46}$ After his departure, the business operations on the European Continent were executed by a daily conference involving the board members who remained in Basel. Important decisions were made in the weekly board meeting with the consent of Brugger, a board member of Basler Handelsbank and Barell's official proxy.

Barell found a base for himself in the U.S. subsidiary in Nutley. Bobst, the head of the Nutley operations, had good tactics. Barell, his family, and even his housemaid started their life in exile in Bobst's residence. Moreover, his new office was opened across from Bobst's office in Nutley.

Barell's priority was to establish communication with Roche's subsidiaries in the Western hemisphere and the Far East. An unauthorized plan was pursued to transform Nutley from a mere U.S. headquarters to the global centre for all overseas subsidiaries - one that would provide products, technical assistance, and managerial instructions for all the overseas subsidiaries. As part of this process, a foreign division was established at Nutley. A number of managers and researchers were transferred to the United States starting from the fall of 1940 all through the following year. These measures had a clear objective. Most of the subsidiaries and agencies within the Allies' sphere of influence came under the supervision of Nutley, and it became the de facto global headquarters. ${ }^{47}$

45 This preparation continued through mid-June; however, it was not really utilized after a period of ostensible stabilization. Widespread defeatism could explain this return to a business as usual mode of working.

46 Of the six executive officers located in Basel, two others travelled to the United States during the war; see Peyer, Roche, pp. 158-159.

47 In this situation, the general meeting of the shareholders of Sapac, which was now registered in Panama, was held in the office of Roche's U.S. subsidiary located in Nutley, New Jersey; see Roche Historical Archive: Box Nr. PAE.2. BAE_101622_I XIII, Sapac Corporation II. Offiz. Correspondence Shareholding. Documents sent from Sapac Corporation, 20 Avenida A, Pana- 
Thus, Roche gradually transitioned to a twin management structure (NutleyBasel) similar to the twin ownership structure (Panama City-Basel) in order to cope with the division of the market according to the two spheres of influence. ${ }^{48}$

\subsection{Telecommunications across the Atlantic during WWII}

It would be interesting to explore how Roche organized communication across the Atlantic. This communication can be partially reproduced using the materials preserved at the Roche Historical Archive. ${ }^{49}$

Since the beginning of the double blockade, overseas communication was carried out using telecommunications tools like the post, telegraph, and telephone. At the same time, documents and memoirs were often entrusted to a third party. In addition, business trips and migrations of executives and other staff members also played important roles.

All official correspondence by telegram and postal mail were assigned a serial number every year to ensure that nothing was lost during transmission. All communications referred to this serial number together with the date of dispatch, in order to avoid misunderstanding. Postal mail was usually duplicated and the two copies were sent separately. The communication of detailed information with rich nuances mainly occurred via post. ${ }^{50}$

The use of telegrams was also quite frequent; in this case, the messages were normally very short (ranging from 20 to 100 words) and used simple language. Almost all the telegrams were written in English. Roche never used codes or

ma City to "Sirs", c/o Dr. E. C. Barell No. 2 East 86th Street, New York 28, New York, dated 12.10.1944 and 12.04.1945.

48 Between September 1939 and December 1941, there was a third sphere outside the outer blockade consisting of the neutral, non-belligerent, and straddling countries (typically Latin American countries). It was both economically as well as strategically important for the other two camps. For Roche, these countries were important as markets and as venues to carry out the complicated schemes for the protection of its interests (such as Panama). However, access to these regions was largely controlled by the Allies.

49 Roche Historical Archive, Document Nr. PE. 2. BAE 101638. Korrespondenz A. Fuchs mit Herrn D. Barell; Document Nr. PE. 2. BAE 101622 Akten Dr. Barell, Aufenthalt in Nutley 1940-1946; Document Nr. LG. US-101979. 17 Ordner Korrespondenz mit Nutley von 1940 bis 1952.

50 Peyer, Roche, pp. 159-160; Roche Historical Archive, Document Nr. PE. 2. BAE 10638, a-f., Korrespondenz A. Fuchs mit Barell and Document Nr. PE. 2. BAE 10625, 1-11. 
ciphers in any of these communications. ${ }^{51}$ This was presumably because they did not wish to attract needless attention from the Allies. ${ }^{52}$ Roche had been questioned by the American and British Consuls in Basel about a few seemingly dubious telegrams that were related to its trade with its German subsidiary. This incident left a strong impression on the Roche executives; they realized how well organized the Allies' telegram censorship system was..$^{53}$ Roche was able to convince the Allies that it was just a groundless allegation made by its competitors, and that the group as a whole had far stronger commitments to the Allies than it had to the Axis. In order to avoid being blacklisted, being open was deemed crucial. ${ }^{54}$

\subsection{Roche's secret group structure and the Allies' perception of the group structure}

Concerning the company's most delicate secret, i.e. the holding structure of the Roche group (twin structure, complicated ownership, and trust schemes), only scattered and indirect information could be found among the various correspondences. Almost all the overseas companies that were founded either directly or indirectly by Roche appeared to be independent companies. Communications with Icaza (a law office in Panama) and with Nadir Corporation (the dummy company that was also in Panama) were such examples. Without focused attention on the issue and a systematic reconstruction of the available, scattered information (which was only possible with a retrospective overview half a century later), it was almost impossible to pin down the ownership and management structure of the Roche group.

51 For a discussion of the role of telegrams in WWII and security issues in general, see: D.H. Headrick, The Invisible Weapon. Telecommunications and International Politics, 1851-1945, New York 1991, pp. 214-274.

52 In the case of Georg Fischer, which had subsidiaries in Germany and in the United Kingdom, the language of correspondence with the U.K. subsidiaries was changed from German to English after the war broke out. Additionally, the postal mail to its Swiss headquarters was not addressed to the company office but to the personal address of the directors. These measures were adopted to steer clear of the Allies' mistrust and to avoid being blacklisted; seeWipf, Georg Fischer, p. 496.

53 Fuchs, Aus meinem Berufsleben, Vol. II, pp. 307-314.

54 Roche often invited American and British diplomats to its factories. Georg Fischer also followed this practice; see Wipf, Georg Fischer, pp. 116-122. 
As for the existing core structure of the group with the twin relationship between Roche and Sapac, connected by identical shareholders who legally had no official ties, it can be assumed that U.S. authorities were aware of it to a certain degree. However, the rest of the complicated protective measures (in anticipation of a possible German occupation of Switzerland) and the transactions and trust schemes among the various dummy companies were kept secret despite the suspicion and tenacious queries of the FBI and other American authorities. ${ }^{55}$

Roche succeeded in evading scrutiny for multiple reasons. Firstly, the focus of the U.S. authorities was on national security and possible cloaking by the Germans. Since the shares of Roche and Sapac were not listed and were mostly Swiss-owned, there was not much to hide, theoretically..$^{56}$

Secondly, as long as there was no pro forma illegality, what was more important was whether the group was really committed to the Allies and if it was ready to cooperate. Thirdly, as for pro forma legality, Roche's group structure was not illegal; thus, there was no ground for compulsory investigation. Fourthly, Switzerland was eventually spared from German occupation, and the prearranged set-up was not fully mobilized. Fifthly, in these situations, the suspicion about Roche's activities focused on the company's involvement in cartels and tax evasion; the authorities focused on the possibility of imposing taxes on the transfer of dividends from its U.S. subsidiary to Sapac in Panama. ${ }^{57}$

55 How exactly Roche succeeded in doing this is beyond the scope of this paper; this would need to be taken up in future research.

56 Since Roche's shares were bearer shares, that is, the shareholders were by definition anonymous, it was not easy for the company to prove this fact. Eventually, the U.S. authorities froze U.S. Roche's transfer of dividends to its foreign shareholders. Thus began a long-lasting litigation against the U.S. authorities. Roche kept its shareholder composition secret until the end of WWI. After the war, the company convinced the authorities about the facts and succeeded in getting the freeze lifted; Fuchs, Aus meinem Berufsleben, Vol. II, pp. 293-297. When the U.S. authorities scrutinized Roche's assets for unblocking the company's frozen assets held in neutral countries, they accepted the Swiss statement, according to which 78 percent of the shares of the parent Roche company was held in Switzerland and less than one percent was in Germany and Japan; Wilkins, History of Foreign Investment, p. 572.

57 When a foreign subsidiary's business in the United States surpassed half that of the parent company, the U.S. tax authority tried to levy taxes on the profits of the U.S. subsidiary as well as those of the parent company in another country. This policy resulted in a long-lasting litigation in the United States; this motivated Roche to implement a fundamental measure for avoiding such taxation by reorganizing its distribution network in South America after WWII; Fuchs, Aus meinem Berufsleben, Vol. II, pp. 326-347. 


\subsection{Expansion of the U.S. business and ambition to Americanize Roche US}

During WWII, Roche's U.S. business dramatically expanded thanks to its strategic shift toward the West and the increased demand for vitamin products and penicillin, the two mainstays of its business since the early 1940s. The staffing level at its U.S. subsidiary increased from 669 in 1940 to 2,000 in 1945, surpassing that of the Basel headquarters, which grew from 800 to 1,200 during the same period. ${ }^{58}$ In 1935, the revenue contributions of the Swiss headquarters, the U.S. subsidiary, and the German subsidiary to the group revenue were a little less than 20 percent each. The American revenue grew 17 times by 1943, constituting a majority of the group's revenues. ${ }^{59}$ Most of the pharmaceutical products were produced in the United States even before the war; during the war, the research and development (R\&D) function was beefed up to position the U.S. subsidiary as the group's largest research base. Roche grew to be the biggest provider of vitamins to the Allies during the war. ${ }^{60}$ The company started the production of penicillin in 1943 at the request of the U.S. administration.

However, this rapid expansion of the American business destabilized the management structure of the group. ${ }^{61}$ In the summer of 1940, taking advantage of his perceived friendship with Barell (who was in a weak state of mind, which was common to people in exile), Bobst managed to convince him that American capital was necessary for the survival and expansion of Roche's business interests in the United States. ${ }^{62}$ To Fuchs' astonishment, the executive committee

58 Peyer, Roche, p. 159.

59 Straumann/Wildmann, Schweizer Chemieunternehmen, p. 181.

60 The U.K. government introduced the compulsory addition of vitamins to white bread to prevent malnutrition of their citizens during WWII. Roche took a risk and invested in a largescale vitamin factory; soon, it became the main supplier of vitamins as a food additive; Peyer, Roche, pp. 293-303.

61 Fuchs, Aus meinem Berufsleben, Vol. II, p. 159.

62 The U.S. subsidiary's ambition for independence was closely linked to Bobst's personal greed. During the war, he started to use the title of Vice President without permission from Basel; subsequently, he gained the official title of President by putting pressure on the parent company, arguing that it was necessary to display American patriotism and to dispel scepticism toward Switzerland. Moreover, he added an unusual clause in his employment contract: he would receive 5 percent of the company's corporate pre-tax income as annual compensation, along with his already high salary. During WWII, the tax rate on corporate income was increased up to 80 percent. Therefore, Bobst's annual compensation could translate to an exorbitant amount compared to what Roche US paid as dividend to its parent company. Barell 
and the board of directors in Basel approved of this project. In Basel, with the exception of the financial director, none of the managers had the knowledge or the information required to make a sound judgment regarding this matter. Access to objective information about the political situation in the United States, especially about public opinion and the authorities' criteria, was quite limited in Switzerland. The sense of uncertainty about Nazi-dominated Europe might have had a role to play in this context.

To realize this project, the legal agreement between Roche Basel and Roche US concerning the rights and obligations (including royalties) needed to be redefined. This was a complicated matter and the group's president sought a one-to-one meeting with his right-hand man to get a second opinion. Thus, Fuchs ventured another journey across the Atlantic.

\subsection{Fuchs's first wartime journey to the United States (late September-December 1940)}

In this section, we follow Fuchs' path to the United States in the summer of 1940, one year after the outbreak of WWII. His aim was to understand the U.S. listing project. Switzerland was already besieged by the Axis Powers. Thus, his mission was to break through the double blockade and build a bridge between Roche's two headquarters.

Despite mobilizing all the organizational capabilities of the large MNE, Fuchs' travel was riddled with difficulties. The process of obtaining a U.S. visa was not complicated because the United States was not yet involved in the war. However, getting transit visas for France, Spain, and Portugal were wearying processes. After great struggle, Fuchs finally got the necessary visas. Additionally, he offered to work as a diplomatic courier connecting Bern with Washington D.C. and New York. Although the Swiss Foreign Ministry (Politisches Department) approved of his request, it did not issue him a diplomatic passport; instead, he was simply given a letter of recommendation testifying that he was carrying parcels for the Swiss diplomatic establishments in the United States. ${ }^{63}$

At the end of September 1940, Fuchs departed from Genève. He took the only loophole available for civilian travellers - the route via Lisbon. Since the railway system in France was not functioning, he took a bus connecting Genève

brushed aside Fuchs's sharp criticism of this issue and argued that changing his contract during the war would not be ideal; Fuchs, Aus meinem Berufsleben, Vol. II, pp. 246-249).

63 Ibid., pp. 185-187. 
and Barcelona, which was operated by a Swiss company. His travel through southern France was filled with hardship. At the border between France and Spain, he was told that the border was closed off. The passengers of the bus were informed that because Portugal had closed its borders, Spain was unwilling to risk allowing transit travellers into their territory. Only employees of companies with a residence permit for Spain were exempt from this general measure; Fuchs forced his way through the border claiming that he was qualified to be in this category. At the immigration office on the Spanish side, the letter issued by the Swiss foreign ministry helped him. ${ }^{64}$

The journey from the French-Spanish border to Barcelona was also exhausting. He took a train from Barcelona to Madrid. The Spanish-Portuguese border was open. In Lisbon, Roche Portugal's staff managed to book him a hotel room. Since Lisbon was the sole way out to America and a dead end in Europe, the city was full of refugees and travellers. ${ }^{65}$

In Lisbon, Fuchs received a telegram informing him about Barell's illness. He was instructed to go back to Basel, but Fuchs decided to continue his journey. He took a flight from Lisbon to New York, with transfers at Azores and Bermuda. At the immigration counter in Bermuda, holders of diplomatic courier were treated very favourably. ${ }^{66}$

In the United States, Fuchs postponed his meeting with Barell (since the latter was sick) and made a transcontinental journey. When Fuchs finally met Barell, he was shocked by how the latter had weakened. After a while, Barell recovered to an extent and was discharged from hospital; he returned to his room in Bobst's house. Soon, a meeting was held to discuss the listing of the U.S. subsidiary on the NYSE.

The meeting in Bobst's private house was attended by five representatives of the company (including Barell, Bobst, and Fuchs); it turned out to be a heated discussion that lasted over ten days. ${ }^{67}$ At the beginning of the meeting, Barell revealed that the U.S. subsidiary's stocks would be listed on the NYSE and that negotiations with Hornblower \& Weeks, the managing underwriter, were in progress. Barell quite convinced about the necessity of this project. The other directors who had moved from Basel also supported the plan; even the Basel headquarters had notified its basic endorsement, leaving Fuchs as the sole voice of opposition. During the discussion, Bobst spoke eloquently, stressing

64 Ibid., pp. 187-194.

65 Ibid., pp. 154-201.

66 Ibid., pp. 204-211.

67 Ibid., pp. 217-223. 
how Europe was in chaos and in deep political, economic, and financial difficulties, that all the directors in exile in America as well as Roche's shareholders should appreciate the fact that Americans were offering a lifeboat to save a large part of the Roche group, and that Roche could reward this support by offering the American public a chance to participate in Roche's profits.

Fuchs could not possibly buy this argument. He was apprehensive about the fundamental restructuring of the group that would be necessitated by the listing and was hesitant to accept the idea that the United States was a safe zone (i.e. it was free from the war). Additionally, there were concerns about the issue price. These concerns were based on the strong sense of uncertainty about the future; the concerns also involved the intellectual assets and human resources that would need to be transferred from Basel. Fuchs felt that the proposed price did not reflect the value of such assets. To him, this listing seemed to be a mere asset transfer to the United States that would result in distinct disadvantages to the existing shareholders.

At the same time, the conditions for supply from Nutley to the Western hemisphere and the Far East formed the focal point of the discussion. Bobst disclosed that Nutley was already providing technical advice and semi-manufactured products to Roche's subsidiaries in Rio de Janeiro, Buenos Aires, and Montreal, and that it was getting payments for these products and services. Bobst argued that these relationships were good enough reasons to make Roche US the owner of these three companies in the Western hemisphere. ${ }^{68}$

The news of Nutley's progress in these matters was a great shock to the financial director. The truth was that Bobst had exploited Barell's illness and had gone behind the parent company's back. Roche Basel was doing its best to separate ownership from the intellectual property rights and supply relations with its subsidiaries, which was the very reason for Sapac's existence. However, the U.S. subsidiary had casually stepped over the headquarters' carefully drawn line for minimizing political risks and had even dared to try to extend it to the direct ownership relations. If Roche US were to play the same function as the holding company Sapac did, it would necessitate a dangerous fundamental change to the group structure.

Such an expansion of Nutley's functions was also not reflected in the proposed issuing price, and it would cause damage to the company's existing shareholders. If the decision to transfer the ownership of the Latin American and Canadian subsidiaries from Sapac to Roche US had been made after the IPO at the NYSE, this plan could still have been cancelled. However, once this plan

68 Ibid., pp. 223-227. 
was included in the listing prospectus and the new shareholders purchased the discounted new shares, it would be impossible to cancel the plan.

After ten days of debate and Fuchs' rejection of Barell's compromise (a proposal that included 51 percent shareholding for Roche US in those three companies), the discussion came to a deadlock. As Bobst began his favourite story about the refugees who sought sanctuary under the aegis of the Stars and Stripes, Fuchs interrupted him: "You seem to be convinced that nothing will change in the United States, and that economic and financial difficulties in Switzerland will persist. But haven't you ever imagined a totally opposite situation, in which the United States will be drawn into the war, taxes will be raised, and so all the bases of your calculations will be overturned? If this were to happen, would you take full responsibility for the consequences?"69 With nobody answering this question, the discussion ended.

The next day, Fuchs' defeat became obvious when the telegram to be sent to Basel was drafted; the basic idea of Barell's compromise was maintained in this communication. Fuchs gave up opposing it and signed the communication while keeping alive the faint hope that the board in Basel would pay attention to the disagreement that he had voiced. He prepared for the issuance of shares and worked on this communication over the weeks that followed.

In late November 1940, Fuchs left the United States. In Bermuda, his luggage (including the diplomatic documents and all the documents about the listing of the U.S. subsidiary) was inspected. The journey from Lisbon back to Basel was again tiresome. ${ }^{70}$

\subsection{A game-changing phone Call: Last-minute volte-face at midnight (Spring 1941)}

After Fuchs' return to Basel, there was no notable news on the progress of the listing project. The listing prospectus was printed but it was not sent to Basel. Fuchs had to obtain it privately from a friend who worked for a bank in Basel. He was shocked to find the clause that allowed five percent annual compensation for Bobst. Instead of a single-year contract, Bobst's position was guaranteed for five years. He had convinced Barell that such a stable status of the com-

69 Ibid., pp. 228-229.

70 Ibid., pp. 230-242. 
pany's president (who had to be an American national) was indispensable for the success of the listing project. ${ }^{71}$

However, the game was not over yet. In the spring of 1941, during the final stages of the listing process, Emil Barell made an international call to Fuchs. ${ }^{72}$ This took Fuchs by surprise because he was usually given prior notice about international phone calls. This time, Fuchs received a call at midnight without any advance information. Barell was in deep dilemma and had trouble making up his mind; he wanted Fuchs' advice. This was unlike Barell, who was usually authoritarian toward his subordinates. The group president confessed that the issuing of shares was running into trouble because of certain demands made by the U.S. Securities and Exchange Commission (SEC). In its hearing, the SEC had requested him to disclose all information about the Roche group's structure. ${ }^{73}$ The SEC demanded that he take responsibility for this information not as President of Roche Basel but as an individual. Barell voiced his anxiety about the project for the first time. He had begun to feel that his American colleagues were serving their own interests, not those of the Roche group at large.

Fuchs did not let this precious opportunity pass. He emphasized that the war had just begun and that nobody knew what would happen next. A personal guarantee would be extremely precarious, given the possibility of Nazi Germany's occupation of Switzerland and of America engaging in the war. In short, he expressed the Swiss view of the situation. Barell found his argument convincing and appreciated his advice. Thus, the painstakingly prepared listing project was abruptly dropped overnight.

This episode of the final decision regarding the listing of stocks on the NYSE is an outstanding example of the power of the real-time, nuanced, and emotioncharged communications that are possible over the phone. This single longdistance call did cost the company a few thousand francs, but it saved the integrity of the group. ${ }^{74}$

71 Ibid., pp. 246-249.

72 Ibid., pp. 249-255. The date of the call is not specified.

73 The SEC had good reason to ask for this disclosure. If Roche Basel was owned (even partially) by the Germans or anybody who had close ties with the Axis Powers, Roche's assets could be confiscated eventually (at least partially). This would certainly jeopardize the interests of the Roche US shareholders. In this context, the authorities in charge of the economic warfare of the Allies as well as the SEC were interested in Roche's ownership structure.

74 After this volte-face, Barell's relationship with Bobst noticeably cooled. Barell moved out of Bobst's house into an apartment facing Central Park. 


\subsection{Financial director Fuchs' second wartime journey to the United States (June-September 1942)}

After the Japanese attack on Pearl Harbor and the subsequent American entry into the war in December 1941, Barell called Fuchs to the United States once again. ${ }^{75}$ He wanted to have an intensive discussion with him, especially given the new situation.

However, at that stage, it was already impossible to obtain a U.S. visa just for business. Barell proposed to meet Fuchs in Havana, Cuba, while enjoying a family holiday there. Fuchs asked the Swiss Ministry of Foreign Affairs to intervene and managed to get a visa for Cuba. However, Barell's re-entry into the United States after his visit to Havana was not guaranteed. Therefore, this plan was aborted.

Despite these setbacks, Fuchs' second wartime trip across the Atlantic followed in a few months. Barell informed his subordinate that the situation was becoming increasingly pressing. Fuchs mobilized all his connections. The American Consul in Basel (who was friends with Fuchs and his family) promised to do his best, but the outcome was uncertain. Consultations with the Swiss government benefited Fuchs. At that time, the Swiss Bankers' Association (Schweizerische Bankiervereingung) was asking the Swiss federal government for diplomatic intervention in the matter of securities and other goods that had been confiscated by the British authorities in Bermuda. The U.K. office in Bermuda was in charge of censorship in the Atlantic. The office was also a competent authority as the judicial body for all goods confiscated during the war in that region. Fuchs requested his government and the Swiss Bankers' Association to allow him to function as a Swiss diplomat to handle this issue, for which a negotiation with the U.S. authorities in New York was indispensable. This proposal worked out and he was issued a diplomatic passport; he obtained a U.S. visa as well as visas for all the transit countries. ${ }^{76}$

On June $6^{\text {th }}$ 1942, Fuchs opened a bottle of champagne at Hotel Drei König, the residence of the American Consul. The Consul had arranged a farewell dinner for Fuchs. The host entrusted Fuchs with a personal letter to his daughter and advised him to watch out for tails planted by the American authorities; he also told him to keep all necessary documents ready to avoid any miscommunication in the event of an interrogation. He dropped by at the Nestlé head-

75 Fuchs, Aus meinem Berufsleben, Vol. II, pp. 255-260.

76 Ibid., pp. 258-259. 
quarters in Vevey, where he was asked to visit Nestlé's president, Eduard Müller, who had moved to a suburb of New York (Stamford/ Connecticut). ${ }^{77}$

Though his second journey during the war was also tiresome, Fuchs reached the United States in a few weeks. He took a train from Genève to the Spanish border, and further to Madrid, and finally took an airplane to Lisbon. There, he was informed by an airline staff member that his name was on the American blacklist; therefore, he was not allowed to board the flight. After contacting the Swiss authorities, it became clear that he had been mistaken for a different person on the blacklist with the identical name. From Lisbon, he travelled further the same way as he did during his previous visit. The U.K. authority in Bermuda interrogated him but did not prevent him travelling further. Later, he learned that Bobst had tried to block his journey. The battle between Fuchs and Bobst, in which the latter leveraged all his American connections, had begun even before Fuchs' arrival in New York.

In New York, Fuchs spent a lot of time with Barell. He consulted with several Wall Street law firms about the possibility of revoking Bobst's employment contract. However, this effort proved futile. An open conflict with Bobst seemed too risky because of the nationalistic atmosphere after the U.S. engagement in the war. Fuchs hammered out a lucrative employment condition for Bobst, which the latter accepted. Although it cost the company a lot, both parties stood to gain from reduced tax payment. Soon after this, Bobst left Roche US; he retained the right to receive substantial remuneration as an external advisor. ${ }^{78}$ At any rate, his leaving the company finally removed the risk of break-up that the group had faced. ${ }^{79}$

\section{Conclusion}

What are the implications that can be derived from the case dealt with in this study? Firstly, the political situation and military events of that time resulted in higher uncertainty than the economic events did; therefore, political events

77 Roche and Nestlé had a close business relationship thanks to food products with vitamin additives. Both companies had created twin corporate and business organizations with the same objectives; Kurosawa/Wubs, Swiss and (Anglo)-Dutch Multinationals.

78 Fuchs, Aus meinem Berufsleben, Vol. II, pp. 260-284

79 Bobst later joined Warner-Lambert and nurtured it into a global pharmaceutical producer; see Peyer, Roche, p. 162. 
were recognized as the more fundamental risk factors to the organization, and these determined the organization's survival strategy.

Secondly, regardless of the double blockade, intensive communication was maintained between the two hubs of the Roche group that were separated by the blockade. The various means of communication had their own unique advantages and drawbacks. Telegrams were fast but could carry only limited amounts of information; therefore, this means was not suitable for conveying subtle nuances or for extended communication. Complicated information, different reports, and deeds/certificates were sent by postal mail but this mode of communication took time; during the war, there were frequent delays and sometimes, no delivery was made, rendering this mode of communication untrustworthy. Both modes of communication were subject to interception and censorship by the two warring camps. Telephone communication was costly but allowed real time conversations that could convey subtle nuances. Telephone conversations could also be intercepted, but the risk was relatively less due to constraints in the recording methods of the time. Thus, the telephone was utilized as a relatively safe means of communication.

Thirdly, telecommunication itself was not a sufficient means for the sharing of information and knowledge that were indispensable for the survival strategy of the organization. It led to the hollowing out of the ownership of the Roche's U.S. subsidiary and subsequent threats to Roche's governance and management, despite the president and a number of high-ranking executives travelling from the headquarters to the United States to contain the risks. (Ironically, their arrival worsened the crisis in a way.) Under these circumstances, face-to-face negotiations with less time delays and asymmetries in information played a key role.

Fourthly, the differences in perceptions and strategies among geographically separated subsidiaries stemmed not only from the clash of interests among the organizations and individuals but also from the asymmetry of information and knowledge that each of them possessed. Such asymmetries were further amplified by the asymmetry in perception based on prior experiences as well as by differences in the envisioned future from a political perspective and the desirable future image of the company. ${ }^{80}$

80 Although the author tried to follow Fuchs's ideas and footprints in this paper, the discussion would be too one-sided if Bobst and Fuchs were to be juxtaposed simply as an egoist and a "faithful" loyalist to the company, respectively. Bobst had his own logic and justifications. He was the most important contributor to the expansion of Roche's business in the United States, and he deserved high annual compensation according to the predominant business ethics in that country, if the wartime taxation had not been expected. As a foreign private company making profits during wartime, the company was supposed to demonstrate its loyalty to the 
Lastly, the limitations of this paper and issues still to be explored should be mentioned. The paper traced the perceptions and actions of people who challenged the double blockade, but could not verify their rationales by using personal memos or records by third parties, as only those kept by Roche were accessed. In particular, the effectiveness and motivation of its intricate scheme concerning voting rights and ownership should be further examined by using the historical archives of the Allied authorities.

Acknowledgment: This work was supported by the Nomura Foundation (Political Risks and Organizational Structure of MNEs: A comparative study on AngloDutch and Swiss companies: 2010-2012) and the JSPS KAKENHI Grant-in-Aid for Scientific Research (A) Number 23243055.

\section{Bionote}

\section{Takafumi Kurosawa}

Professor of Economic Policy at the Graduate School of Economics, Kyoto University, Japan. His dissertation analyzed the Swiss economy and the formation of the cross-border economic region in the 19th century. He translated the Final Report of the Bergier Commission into Japanese, combining his original research outcomes. His publications in English explore multinational enterprises and political risk, industrial clusters, the paper and pulp industry, and industrial policy. His work includes European as well as Japanese cases. Since 2012, he has been leading a large-scale international research project on the competitiveness of regions, with a focus on the history of industry. Since 2010, he has conducted joint research with Ben Wubs (Erasmus University Rotterdam) on "Political Risks and Organizational Structure of MNEs: A comparative study on Anglo-Dutch and Swiss companies".

American public. For him, the listing on the NYSE was vital for safeguarding Roche's interest (which is where he differed from Fuchs). Considering how Roche's business and autonomy in Europe were doomed, the Americanization of Roche's ownership was deemed the best safeguard against the political risks of that time. However, even by this argument (which sounds ironically closer to the logic of stakeholder value or managerial capitalism), the justification for the unwilling transfer of (family) ownership from the existing shareholders to the new owners in the United States was rather weak, given that private property should be respected. Thus, the legitimacy of the listing project depended on political and ethical values - the perception of a desirable future. In this respect, the views of the two men were in fundamental conflict, which resulted in different ways of thinking and distinct ideas about desirable actions. 